\title{
The Church mission relative to socio-political issues in Francophone Africa
}

\begin{abstract}
Author:
Kalemba Mwambazambi ${ }^{1}$

Affiliation:

${ }^{1}$ Department of Practical Theology and Missiology, PRACTEMUS, University of Stellenbosch, South Africa

Correspondence to: Kalemba Mwambazambi

Email:

profkalemba@yahoo.fr

Postal address:

Private Bag X1, Matieland

7602 , South Africa

Dates:

Received: 05 Nov. 2011

Accepted: 10 Sept. 2012

Published: 01 Nov. 2012

How to cite this article: Mwambazambi, K., 2012, 'The Church mission relative to socio-political issues in Francophone Africa', Verbum et Ecclesia 33(1), Art. \#694, 6 pages. http://dx.doi. org/10.4102/ve.v33i1.694
\end{abstract}

(C) 2012. The Authors. Licensee: AOSIS OpenJournals. This work is licensed under the Creative Commons Attribution License.
The Church mission relative to socio-political issues in Francophone Africa requires a paradigm shift in both practice and teaching. To revitalise the Christian mission and pave the way for the positive transformation of Francophone Africa, a method review and mission strategy is relevant. The Church's mission is to create disciples, to evangelise people, bring them to a deeper faith, promote truth, justice, peace, reconciliation, reconstruction, development and defend the poor and oppressed. Thus, people should always be central to the Church's commitment regarding evangelism and social advancement. This article has provided a missiological overview of the Christian mission to gain a better understanding of the role of the Church in Francophone Africa today.

\section{Introduction}

Francophone Africa faces many socio-political issues today because of poverty, corruption and political unrest. There is a real need for life changes and for spiritual and physical transformation to occur. Thus, the Church is called to proclaim the Gospel of God's Kingdom with uncompromising determination by reaching the unreached people and by taking into account various challenges currently preventing positive transformation of Francophone Africa. Also, the Church must understand the difference between Gospel culture and salvation culture because 'a gospel culture is a culture shaped by following Jesus, by living under Jesus as King. A Gospel culture includes personal salvation, but it is also so much more. A Gospel culture can only be created if we are thoroughly converted ourselves' (McKnight 2011:159). Salvation is the intended result of the Gospel story about Jesus Christ and when the result overshadows the story, we have entered a 'salvation culture' which McKnight (2011:62) argues is designed by God to be a subculture and not a dominant culture. Evangelical Christianity should strive for a gospel culture.

A Christian is one who follows the way of Christ. We learn to describe situations, people and the world through our ongoing participation in the life of a community that seeks to reinterpret the world according to God's victory over sin and death in the person and work of Jesus Christ (McKnight 2011:153). However, to perform its prophetic and holistic mission properly, the Church should commit to a new form of in-depth discipleship by responding to the various hardhitting issues facing Francophone Africa today and by proposing appropriate solutions at all levels according to God's word.

The world Church mission should be 'leaven in the dough' by being in total solidarity with the people, sharing their problems and destiny, and working together for positive transformation. It must move from unnecessary protest to positive reconstruction. Mugambi (1995:6) affirms that 'it's clear that Jesus, in his public ministry, was actively involved in the reconstruction of individuals and their communities. He mobilised his disciples to get involved in social transformation'. Argues Villa-Vicencio (1992:12) said, 'the church is not forced to promote social justice; she may also have in mind the active vision of what society can become'. Dolamo (2001:295) also affirmed this when he said, 'We Christians have to offer a critical and prophetic support for the Government's agenda; we must support the government in those projects whose main objectives are to improve the quality of life for all, especially those which give preferential treatment to the poor'. This is the reason why the Church should participate in the struggle against all forms of socio-political issues (e.g. political conflicts, war, low income and unemployment) still destroying Francophone Africa.

In relation to this, the research questions are, 'What should the Church's mission be regarding socio-political challenges in Francophone Africa today? What should the Church's role be in pursuing social justice and facilitating positive transformation of Francophone African society? Is today's Church mission a continuation of Jesus Christ's ministry? What should the Church do in order to make a difference in Francophone Africa during the rest of the 21st century?' This research will respond to these crucial questions in the hope that the outcome will contribute 
to the missiology field and to positive transformation in Francophone African society. The Church is called upon to revive its earthly mission as it follows the missio Dei and to promote the immediate environment's development through the Gospel and its holistic mission. In the same way that a man or woman is not only an individual, but also forms part of society and culture, so does the Church not exist for itself, but to preach the transforming Gospel to all people. This Good News will have no relevance to human hearts if it falls outside their spiritual and physical core (Kalemba 2012:197).

This article demonstrates and analyses socio-political issues facing Francophone Africa today and the Church's role in positively transforming African people and their societies. The article is subdivided into four parts: introduction, research background and development, missiological response and suggestions, conclusion and bibliography. The analytic-theological research method is used.

\section{Background and development}

In just over 50 years, many Francophone African countries gained political independence from colonial powers. Independence gave rise to great hopes of political, economic, social and cultural development. Today, unfortunately, the reality is quite different as most Francophone countries, such as the Democratic Republic of Congo, Republic of Burundi, Cameroon and Central African Republic, still experience major poverty and suffering. Issues of poverty in Francophone Africa resulted in a 'lack of social intelligence and spirituality' for many Francophone African people because some 'African people destroy themselves and their countries for personal gain and of [sic] a lack of love for others' (Kalemba 2012:197). This situation is sometimes caused by poor governance, corruption, political conflicts and personal interests of the Francophone African leaders. Alemazung (2011) argues:

Amongst other problems, constitutional change, as it suited the power greed of African leaders, embezzlement of state funds, succession by their offspring, the use of state security forces to oppress the people, ethnic divisions and widespread corruption become a canker worm to political leadership in Africa, with overwhelmingly devastating effects on the societies. (p. 31)

As an example, the Democratic Republic of Congo is currently experiencing large Christian leadership challenges and political incoherence because of poverty and corruption amongst some Christian and political leaders. Many conflicts in the Democratic Republic of Congo arose, firstly, from personal interests and secondly, from community interests. There is a new political culture emerging amongst Congolese leaders which is against traditional African values. Consequently, as stated by Kalemba (2011):

Congolese plot against other Congolese, Congolese kill other Congolese, Congolese political leaders kill themselves, their sisters and brothers in different ways for their own interests and they create complex problems with people outside the country. (p. 17)

In addition, 'corruption is considered as an opportunity for some Burundian and Congolese people' (Harimenshi 2011:6).

\section{Poverty problems}

Poverty in Francophone Africa means a lack of basic human needs and currently, many Francophone African people live on less than $\$ 1$ per day. Incidences of extreme poverty are not decreasing despite decades of work by African governments and Non Profit Organisations (NGOs), outside NGOs and foreign government aid programmes. Poverty in Francophone Africa does not result from only one or two causes. There are a number of different factors contributing to the situation and some of the major causes are corruption, rampant unemployment, low-incomes, lack of access to education, disease, inadequate nutrition, political conflicts, et cetera.

According to 'World Bank statistics for 2008, 47.5 percent of sub-Saharan Africa is below this poverty line. Twenty-two of the twenty-four countries listed globally as having Low Human Development' were based in sub-Saharan Africa in 2009 (http://www.actionagainsthunger.org). Today, 89\% of the Congolese people are unemployed and every year malnutrition kills more than 50000 children in Cameroon (Claude 2010). Chad is subject to many geographic disabilities and deep political damage exists. Corruption in Chad is leaving the nation and people at a severe disadvantage. Corruption in the Republic of Burundi enhances poverty and inhibits beneficial advancement (Harimenshi 2011:4).

In the global context, imbalances in politics, economics and policy have had very serious consequences with regard to the economic development of Francophone Africa. In fact, globalisation has caused poverty and inequalities to grow in Francophone African countries such as Central African Republic, Democratic Republic of Congo and Republic of Burundi because of low income and unemployment. Prabhakar argues (2007:303) 'globalisation refers to [the] transformation of national capitalism [into] global capitalism. In the main, policy decision-making processes and choices are dictated by international institutions of governance'. Consequently, the national development of Francophone Africa is affected by dominating developed countries as well as by petrol profits and selling of arms. As Prabhakar (2007:304) affirms, 'globalisation policies contributed to increased poverty, as well as increased inequality between and within nations'. Thus, national development is considered a multi-dimensional process, using sustainable resources to relieve poverty and improve the nation's socio-economic standard of living. However, Francophone African countries are considered to be third-world countries, characterised by socio-economic poverty, human rights violation, low income and joblessness. According to Kalemba (2011):

weak economies, owing to the lack of domestic economic capacity and weak social infrastructure, the power of the international financial institutions generally shows a preference to serve the interests of the wealthier countries. (p. 21)

Economic mismanagement, morality, social injustice and corruption also sabotaged the national development of Francophone Africa. For example, the Democratic Republic of Congo has been further weakened by low export prices, 
the debt crisis and the burden of debt servicing. Conditions attached to loan rescheduling packages have hampered the recovery of the Congolese economy and led to a further deterioration in their social services (Kalemba 2011:21). He also states that the suffering of the:

majority of people is characterised by the tragedy of poor people in a rich continent full of natural resources. It is also the consequence of weak behaviour of some political leaders, beliefs, unethical laws, and theories and practices implemented through government and parliament. (Kalemba 2011:22)

Without a strong culture of community development, spirituality and a healthy social conscience in servicing Congolese society as a whole, the Democratic Republic of Congo will not develop into a strong democracy in the future. This applies to Francophone Africa as a whole as well.

However, the Church can play a major transformative role in this situation as it fulfils the missio Dei by educating people and their leaders, eradicating ignorance, poverty and corrupt political leaders, and by promoting discipleship. As Dolamo (2001:296) affirms, 'Reconstruction and development cannot be successfully undertaken and reconciliation effected without adequately addressing the issues of economic justice'. Dandala (2001) adds:

social transformation, fairness and justice must be understood as an intrinsic fabric of reconciliation; reconciliation is not possible where the contending factions do not have a common understanding of the truth. (p. 30)

\section{Corruption and political challenges}

Corruption is destroying Francophone African countries in various ways. It destroys the economy, social life and morality of a country. Corruption is, inter alia, the misuse of state property, and is tragic for all involved. This is a serious scourge in Francophone Africa and affects everyone and all sectors of society in various ways. It is even 'found in Christian communities because it perverts the financial life of parishes and local churches' (Kalemba 2011:18). Corruption affects many areas of society as underscored by Privat-Biber (2004:12) who wrote, 'like any challenge, it can be solved if people act individually and collectively as part of their possibilities'. Corruption has two alarming constants; firstly, it is found mostly amongst high level officials with greater responsibilities and in higher level institutions (Harimenshi 2011:6). Secondly, according to Harimenshi (2011) many Francophone:

African children are born and grow within this system of corruption, which distorts their consciousness from an early age into believing that success is achieved not by study and honest work but by corruption, theft and cheating. (p. 6)

He also states that the:

corrupted people consider today as naive those who are not involved in corruption and live honestly. Moral values are disregarded to the extent that the cheaters are called strong, brave and intelligent. (Harimenshi 2011:7)

In our present day moral rectitude, dedication and work attendance are regarded with contempt. As a result, corruption has reached high levels in the Democratic Republic of Congo, namely, in Republic of Burundi and Congo-Brazzaville. It is currently accepted as a normal way of life, so much so that people no longer have any practical sense of guilt. Kalemba (2012) affirms this when he says:

corruption is a virus that plagues all aspects of social life in Africa; corruption hurts, it kills the men and women; corruption creates an unjust society that no longer guarantees equal rights and opportunities for its citizens. (p. 205)

According to Mpoyi (2010) it creates a:

climate of suspicion and distrust amongst individuals; it condemns them to live in fear and insecurity; corruption is also the root of more political crises in Democratic Republic of Congo. (p. 38)

Corruption leads to the destabilisation of many political state institutions. In the Democratic Republic of Congo, some political leaders use corruption to maintain power and others 'buy' the peoples' conscience to conquer existing authorities and win elections. In such cases, 'these politician leaders take state treasuries hostage and regard them as their own property, and nobody has the right to demand transparency in the management of these treasures' (Kalemba 2012:206). Thus, 'few politicians and administrative authorities demonstrate the love of heritage but most politicians began illicit enrichment because the corrupt mock justice' (Harimenshi 2011:10). Claude (2011:64) affirms this when he says, 'in most African countries, political projects are highlighted to convince the voters but rather the corruption that is used before, during and after election campaigns'. For example, during the 2012 presidential and legislative elections in Democratic Republic of Congo, more sociopolitical troubles and collapses took place because of some corrupt political leaders. Consequently, the Democratic Republic of Congo is in a chaotic situation and, as a result, the people suffer through conflicts caused by political corruption and leadership crises. Corruption keeps investors out of the country, stifling industrial development, which in turn, leads to job creation (mines, factories, etc.). No 'new' knowledge comes into these countries and thus people stagnate.

Corruption often cripples Francophone Africa's economies. People are discouraged from securing self-financing for small projects when political and administrative authorities require various bribes. Furthermore, 'corruption enables domestic and foreign investors to avoid paying taxes as they should and the coffers of the State are emptied' (Claude 2011:86). Mpoyi (2010:49) says, 'the State enterprises go bankrupt because of corruption and misappropriation of funds. Therefore, the Congolese government is forced to privatize these companies and it creates unemployment'. Examples of corruption abound and have a negative effect on the sociopolitical development of the Democratic Republic of Congo.

\section{Missiological response and suggestions}

Before responding to the research questions posed in this article, we need to define the Church mission in order to 
understand the Church's role in positively transforming Francophone African society. The mission of the church depends, to a large degree, on what is meant by the word 'mission' (Deyoung \& Gilbert 2011:17). However, the word 'mission' as a noun does not occur in the Bible, which makes the question of this book more difficult. But, it is found in the Latin verb mittere which corresponds to the Greek verb apostellein, and which occurs 137 times in the New Testament. So, mission is not exactly extra biblical. The Church mission can be to glorify God and enjoy him forever or to love God and neighbour, as they are the greatest commandments. Because mission is the central calling in the Gospel message, trust and obedience is the essence of the Church's mission. However, Bosch (1991) argues that:

since the 1950s there has been a remarkable escalation in the use of the word 'mission' among Christians. This went hand in hand with a significant broadening of the concept, at least in certain circles. (p. 1)

Mission previously narrowly referred to Christians sent out cross-culturally to convert non-Christians and plant churches. These days, mission is understood more broadly, namely, as evangelism, environmental stewardship, community development, transformation of society, social justice, people liberation, reconstruction, et cetera. As Deyoung \& Gilbert (2011:18) have said, 'Mission is here. Mission is there. Mission is everywhere'.

Köstenberger (1998:199) argues, 'Mission is the specific task or purpose which a person or group seeks to accomplish'. Stott (1975:30) understands mission to be 'everything the church is sent into the world to do'. The Church's mission is to do the things God's word recommends because it is a continuation of the ministry of Jesus Christ between the incarnation and the parousia. This must be done in partnership with God and in his will in redeeming the entire world. Deyoung \& Gilbert (2011:26) affirm this when they say, 'the mission of the church is summarized in the Great Commission passages'. The Church's mission today must be a continuation of Jesus Christ's mission for people's salvation and the coming reign of God (Jn 14:12). The Church should be instrumental in making a difference in non-Christian institutions because Christ commissioned it. Matthew (5:13-16) says, 'be the 'the light of the world and salt of the earth'.

Another important Church mission is to strengthen the body of believers and equip them for Christian responsibilities. Christ's body is called to hear the cries of distress of the oppressed and the poor. The 'church should be an atmosphere of spiritual edification, where God's word is taught, where believers are grounded' (Robbins 1995:2). According to God's Word, each member of the body of Christ is called to serve in

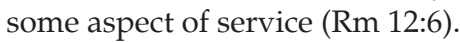

The Church must bear with the suffering of the sick, those displaced by war and excluded from society, refugees, prisoners and those in ethnic trouble. For this reason, the Christian must rise as one man to fight against the scourge of corruption, social injustice, poverty, bad governance, et cetera. Christians represent the interests of God's Kingdom on earth, and should influence society with Christ's ideals. Likewise, according to Robbins (1995):

the presence of the church in the world is Christ's antiseptic to sin, and the church is intended to represent God interests in the affairs of society. It was not intended to be passive, nor to be confined within four walls of a building, but to be involved as a catalyst of God's high ideals in the world. (p. 3)

\section{Church response relative to the poverty issue}

Poverty and disease relate, in part, to a lack of quality education and information. To combat this situation it is necessary to inform and educate people. In connection with the above, the Church has to preach the truth of hard work and shared experiences in transforming negative situations into positive ones. The poor and non-believers can be assisted by reaching out toward one another in a spirit of love and reconciliation. In addition, the Church must, as often as possible, consult with governments, warning and denouncing the dangers of socio-politico-economic exclusion, tribalism, policies of nonforgiveness advocated by some extremists at the expense of national cohesion, non-transparency and bad governance. Faced with various forms of poverty, external and internal debts arising from neocolonialism, the Church should raise awareness and motivate people to challenge the sociopolitical system and persuade Christian leaders to rethink the welfare of Francophone African society.

Educating people is an important factor when addressing issues of poverty and in creating better lives for all. In fact, a continent that does not educate its people is well known as a continent that remains in mediocrity, ignorance and underdevelopment. Clearly, in the current context, providing quality, higher education to people should be a Church priority. Mediocre education is a disease and there is no cure in sight. Thus, to avoid the various issues and diseases currently ravaging Francophone African countries, proper education is of utmost importance. Solidarity must prevail over selfishness. The fight against all diseases can be overcome by returning to God's heart and sowing community seeds of true love, harmony, justice, happiness, security, collaboration and reconciliation.

The Church should also initiate and stimulate new ways of implementing a stronger sense of morality in people's lives. Moral theology can play a major role in transforming Francophone Africa. It can highlight sin and reject visible spiritual complacency. It can inform and initiate reconstructive practice and promote Africans, who are obviously children of God and created in his image. Thus, the church needs to find the dimension that allows it to 'judge the world' by means of its political, prophetic and apocalyptic vision.

Not only does liberation and transformation affect individuals in their daily lives, but it also unites them with their interwoven cultures and the structures that manage their lives. Dolamo (2001) affirms that:

implicitly and explicitly, religions usually include both the spiritual and physical aspects in salvation and liberation. Adherents are also expected to contribute towards the creation 
and enhancement of the communal life in terms of personal and public morality. (p. 294)

For this reason, promoting moral action can bring about a change of mind and heart regarding poverty levels by proclaiming and living the Gospel. This change of attitude would act as 'leaven' for companies by lifting them higher spiritually when they turn back to God. In this sense, moral theology can decidedly look to Francophone Africa and clarify guiding ethical principles. Through commitment, Francophone Africa must be reconstructed and delivered from misery and suffering created and maintained by selfish local and foreign powers. Instead of just appreciating the ethical heritage of traditional Africa and demonstrating its compatibility with the Christian ethos, the Church can also build an ethical discourse.

By implementing the above approach, the Church can stay in touch with the society it is incorporated into, and remain attentive to the society's concerns, strengths and challenges. As emphasised by Kä Mana (2005:19), 'We need a comprehensive look at what we've been and what we are all to invent what we want to be, and what we are really'. This spiritual and physical rebirth is vital to the Church in Africa today. There will be no African Renaissance without a viable awareness of reality and without analysis of the weaknesses, faults and flaws of the current mission system.

Francophone Africa must leave behind the era of endless criticism, unnecessary and unsustainable socio-politicoeconomic crises and internal war, and enter into a paradigm shift with a new mentality and vision. This will be possible only if the Church can play her prophetic and holistic role in transforming people and Francophone African societies. The one-dimensional focus of evangelical missions on personal salvation and the hereafter much change. People's immediate and pressing survival needs cannot be ignored. The aim of evangelisation should also be to change people's mentality. A true spiritual relationship with God (in Jesus Christ) will inevitably lead to a new social attitude and mentality. The people's hearts must be one with Jesus Christ, only then will they follow in his footsteps and his examples.

\section{Church response relative to corruption and political issues}

Francophone Africa is currently confronted by a number of issues including noncompliant human rights, corruption, political exclusion and lack of proper education, people infected with the HI-virus and people living with AIDS, food insecurity and the rhetoric of demagogic politicians. However, the list of concerns and needs of those turning to the Church does not always coincide with the historically established Christian mission and the daily lives of Christians. Thus, it is necessary to establish and integrate the spiritual and physical needs of the people. As Dolamo (2001:292) states, 'The Church by its nature must remain a beacon of hope for those who are struggling from the underside and margins of society'. It is important to rethink Francophone Africa's future in terms of rebuilding socio-political, economical, ethical and spiritual concerns. In other words, in the light of its decay, real personal transformation in the social, political, economic and cultural lives of people must develop.
Francophone African people obviously desire to be free, to grow and become independent. It is important to understand that real, transformation in Francophone Africa requires a tangible change in attitude, a mentality shift regarding social improvement and the adaptation of African traditions to a changing world. In connection herewith, African theologians should promote the Christian mission and the Church's role in encouraging faith in Christ. These combined efforts will lead to the positive transformation of the continent.

Inspired by the Gospel, such a mission should deal with people's every day concerns. The Church in Francophone Africa can do this by motivating those in leadership positions and Christians to discern various key issues. One of these key issues is awareness of national and international exchanges of a global politico-economic nature based on inequality and domination of others. Nürnberger (1989) affirms:

Justice is based on equal rights and equal dignity, and justice based on these two concepts implies a social balance. This balance relates to the distribution of power, wealth and status. (p. 12)

In the current context, the Church mission is to promote social cohesion, peace, justice, reconciliation, good governance, love of God and love of neighbour that is in fact the framework and basis of the Church's mission. It is important to understand that lasting transformation requires a perceivable change of mentality, awareness and sociopolitico-economic improvement.

Robbins (1995) stated that the Church should preach the Gospel of transformation:

which will liberate and heal the inner wounds of the people. It is also important that the Church let its light shine to the world - to love, to care for, and to meet needs of humanity, while upholding the redemptive truths and righteousness of Christ. (p. 3)

Given the continual violations of human rights in Francophone Africa, the Church should, through preaching, highlight the importance of all people according to the Gospel. The knowledge that they are created in God's image will restore people's dignity, and play an active role in the fight against human rights abuses. The Church's mission is to provide biblical answers for 'these worldly needs like sickness, poverty, oppression, unemployment, loneliness, evil spirits, sorcery, etc' (Kalemba 2011:23). The Holy Spiritled Church can, in addition, enhance community life by sharing and living together in love and communal harmony and thus become a true fellowship - a community of peace, justice and shared joy. However, to achieve this, Francophone Africa needs spiritual men and women. The Church must promote spiritual and moral education in all social life areas. This is pointed out by Kiki (2007:70) when he says:

The Church is in a constant struggle against the temptation to set themselves up in an institution rather than remaining static in motion, but it cannot fulfil its mission without getting in touch with its head in total communion with the Holy Spirit. (p. 70)

Pongo (2006) states that the hope:

the Gospel gives is that of a population that sees every human as useful, every individual being prepared to abandon every form of selfishness, to promote the well-being of all. (p. 14) 
The current, obvious role of the Church in Francophone Africa is to follow, with a critical mind, the missionary enterprise in order to examine its motives, goals, behaviour, message and methods for evangelism. Thus, the Church mission, in relation to the dynamic relationship between God and humanity, can consciously continue its work in a context of deeper faith and a more holistic mission. As stated by Bosch (1995):

salvation that Christians are meant to celebrate, and they can testify in word and deed, is manifested in the proclamation of the Gospel as the Gospel is also fighting against all forms of evil, be it personal or social matters. (p. 10)

The Church must re-involve itself in education and developmental strategies.

\section{Conclusion}

The various critical challenges of the Christian mission illustrated above can be a starting point for understanding the socio-political challenges in Francophone Africa and for spiritual reform. However, sin, poverty, corruption, social injustice, breach of human rights, lack of democracy, ignorance, bad governance, unnecessary wars, diseases and gender discrimination are amongst the many challenges facing the Church in Francophone Africa. These challenges can serve as a spiritual thermometer and analysis tool for a holistic mission.

Today's Church mission can, as a result, be redefined as a people-liberating mission. This can be done by leading Africans back to the Kingdom of God by preaching the salvation Gospel in Christ and promoting spiritual and moral transformation. Without a strong Church mission the Church cannot guide and light the way for human salvation. The Church has to act sensitively with regard to creativity and imagination in these societies, as people need a form of escape from the poverty and corruption in Francophone African countries. In the context of poverty in Francophone Africa, the Church should be to be involved with the community's struggle against all forms of poverty.

Faced with the global economy and politics, and the financial and economical problems facing Europe at the moment, Francophone Africa must become independent from Europe and the West. However, there will be no transformation without ethical and spiritual forces to spread inventive synergies. The Church's role in pursuing social justice and facilitating positive transformation in Francophone Africa should be to initiate a new direction in applying strong morality in people's lives. The Church must promote leadership ethics in order to make a difference during the remainder of the 21st century. The Church has to re-involve itself in education and developmental strategies.

Francophone Africa can be spiritually and physically reborn through the Christian faith and so create a healthy society where the Spirit of Christ impels the creative genius of Africa. This means the Church must use its imagination to place Jesus' message of the Cross against the causes and consequences of disorientation and disorganisation in Francophone Africa. Obviously, by providing spiritual substance, the Church can, once again become a powerhouse of faith, moving mountains and cutting paths through rock with God's power. African people will be able to fight against corruption, violence, selfish interest, poverty, poor governance and work together in developing their communities. Furthermore, healing and forgiveness should take place before any other change can occur. African people must make use of God's Word and stay in prayer to achieve this. God's Word and prayer are still the only 'tools' for bringing about positive transformation. The one-dimensional focus of evangelical missions on personal salvation and the hereafter much change. People's immediate and pressing needs for survival cannot be ignored. A true spiritual relationship with God (in Jesus Christ) will inevitably lead to new social attitudes and a different mentality. By following the selfless example of Christ, transformation will come about. The Church's mission is to proclaim the Gospel and make disciples, because the Church's ministry is the continuation of Christ's ministry of the missio Dei.

\section{Acknowledgements Competing interests}

The author declares that he has no financial or personal relationship(s) which may have inappropriately influenced him in writing this article.

\section{References}

Alemazung, J.A., 2011, 'Leadership flaws and fallibilities impacting democratization processes, governance and functional statehood in Africa', African Journal of Political Science and International Relations 5(1), 30-41.

Bosch, D.J., 1991, Transforming mission: Paradigm shifts in theology of mission, Orbis, Maryknoll.

Bosch, D.J., 1995, Dynamique de la mission chrétienne: Histoire et avenir des modèles Missionnaires, Karthala, Lomé.

Claude, K., 2011, Global mission and justice, Med, Kinshasa.

Dandala, M., 2001, 'The role of the church in the birth and nurture of a new nation', Verbum et Ecclesia 22(1), 30-42.

Deyoung, K. \& Gilbert, G., 2011, What is the mission of the Church? Making sense of social justice, shalom, and the great commission, Grossway, Wheaton.

Dolamo, R.T.H., 2001, 'Reconciliation and economic justice in South Africa: The role of the church and Theology', Verbum et Ecclesia 22(2), 292-299.

Harimeshi, B., 2011, La corruption en Afrique, APM, Bujumbura.

Kalemba, M., 2011, 'The complexity of environmental protection in sub-Saharan Africa and the reduction of poverty', Ethiopian Journal of Environmental Studies and Management 4(1), 17-24.

Kalemba, M., 2012, 'Une réflexion missiologique sur le leadership chrétien en Africa', Swedish Missiological Thems 100(2), 195-209.

Kä Mana, K., 2005, La mission de L'église africaine, Cipro, Yaoundé.

Kiki, C.G., 2007, Etre Chrétien en Afrique aujourd'hui, Karthala-Clé, Paris.

Köstenberger, A., 1998, The mission of Jesus and the disciples according to the fourth Gospel: With implication for the fourth Gospel's purpose and the mission of the contemporary Church, Eerdmans, Grand Rapids.

McKnight, S., 2011, The king Jesus gospel: Revisiting the original good news, Grand Rapids, Zondervan.

Mpoyi, K., 2010, Poverty and development, Med, Kinshasa.

Mugambi, J.N.K., 1995, From liberation to reconstruction: Africa Christian theology after the cold war, East Africa, Nairobi.

Ntezimana, L., 1986, Libres paroles d'un théologien rwandais, Karthala, Paris.

Nürnberger, K.T. \& Domeris, W., 1989, Conflict and the quest for justice, Encounter, Pietermaritzburg.

Pongo, F., 2006, La place de la théologie africaine, IFTSA, Kinshasa.

Prabhakar, A.C., 2007, A critical reflection on globalization and inequality, in analyzing contemporary development debates and issues: A reader, compiled by P.D.S. Stewart, University of South Africa, Pretoria.

Privat-Biber, H., 2011, La corruption en Afrique francophone, APM, Burundi.

Robbins, D.A., 1995, What is the mission of the church?, Victorious, Grass Valley.

Stott, J.R.W., 1975, Christian mission in the modern world: What the Church should be doing now, Inter Varsity, Downers Grove.

Villa-Vicencio, C., 1992, A theology of reconstruction, University Press, Cambridge. http://dx.doi.org/10.1017/СВ09780511607592

Water Partners International, 2010, Race against hunger, viewed 18 June 2012, from http://www.actionagainsthunger.org 